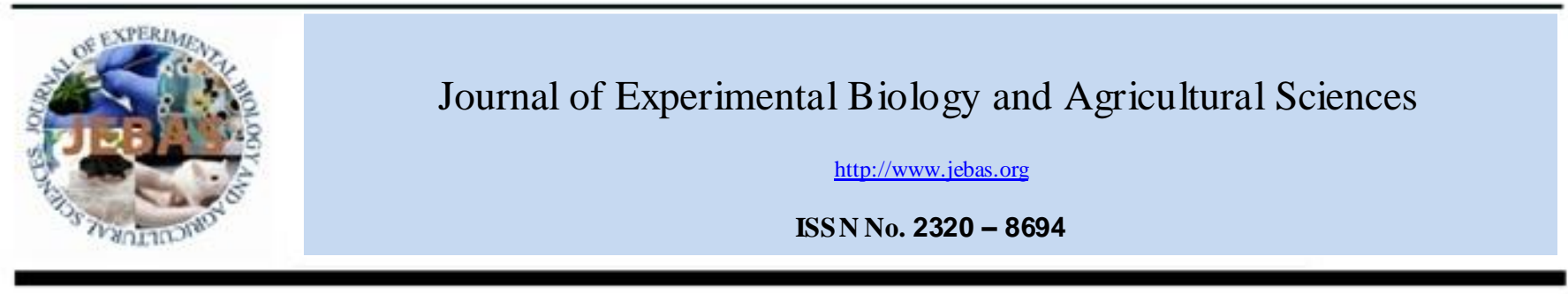

\title{
AGGREGATE STABILITY OF FOUR SOILS AS EVALUATED BY DIFFERENT INDICES
}

\section{Nweke I A ${ }^{1, *}$ and Nnabude P $\mathrm{C}^{2}$}

\author{
${ }^{1}$ Department of Soil Science Anambra State University, Nigeria \\ ${ }^{2}$ Department of Soil Science and Land Resources Man agement, Nnamdi Azikiwe University Awka, Nigeria
}

Received - February 16, 2015; Revision - March 02, 2015; Accepted - May 23, 2015

Available Online - June 19, 2015

DOI: http://dx.doi.org/10.18006/2015.3(3).246.252

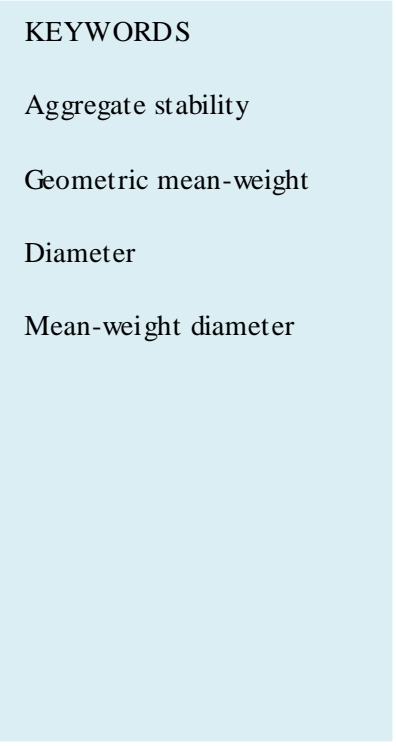

\begin{abstract}
ABSTRAC T
In present study, aggregate stability of four soils viz Entisol, Ultisol and t wo Inceptisols were evaluated using different indices. Soil samples from the depth of $0-25 \mathrm{~cm}$ were collected from cultivated and adjacent fallow lands at the four different sites located, at Nsukka area of southeastern, Nigeria. The soil samples were air-dried at room temperature and then were separated into five aggregate fractions i.e. 5 $2 \mathrm{~mm}, 2-1 \mathrm{~mm}, 1-0.5 \mathrm{~mm}, 0.5-0.25 \mathrm{~mm}$ and $>0.25 \mathrm{~mm}$. Aggregate stability assessments were performed according to the methods of mean-weight diameter and geometric mean-weight diameter which were determined by both dry and wet sieved fractions. The results of the study showed that aggregation of the cultivated soils were less stable than the fallow soils. Furthermore, the aggregation of the cultivated soil disintegrated faster than those of the fallow soils when they came in contact with water. The meanweight diameter (MWD) result of the soil aggregates showed that cultivation reduced the aggregation stability of Nsukka Entisol for dry sieved samples and Inceptisol at Eha-Amufu for wet sieved samples. The mean-weight diameter of wet sieved aggregates though, generally not significant showed that percentage increases due to cultivation were 6.3, 3.2 and 2.9 percent for Entisol at Nsukka, Ultisol at Nsukka and Inceptisol at Ikem respectively and 50.0 percent relative decrease for Inceptisol at EhaAmufu. Geometric mean-weight diameter (GMD) result of both dry and wet sieved samples showed that cultivation reduced the aggregation stability of Nsukka Entisol, Ultisol, Inceptisol at Eha- Amufu and no effect on Inceptisol at Ikem.
\end{abstract}

* Corresponding author

E-mail: nwekeson@hotmail.com (Nweke I A)

Peer review under responsibility of Journal of Experimental Biology and Agricultural Sciences.

Production and Hosting by Horizon Publisher (www.my-

vision.webs.com/horizon.html).

All rights reserved.
All the article published by Journal of Experimental Biology and Agricultural Sciences is licensed under a Creative Commons Attribution-NonCommercial 4.0 International License Based on a work at www.jebas.org.

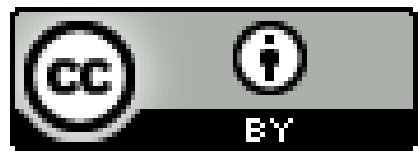




1 Introduction

\section{Introduction}

Soil is the main stay of life and crop productivity is directly depends on the constituents and structural stability of the soil. Soil texture or soil architecture is a crucial soil property which play an important role in maintaining the several important processes related to soil productive capacity, environmental quality and agricultural sustainability (Kay \& Munkholm, 2004). Soil texture plays an important role in development of root, retention of water, capacity of infiltration and porosity of soil (Neves et al., 2003). Structural stability describe the ability of the soil to retain its aggregation and pore space when exposed to external forces such as wind, water, cultivation/tillage. Hence soil structure becomes the foremost factor that determines the soil physical properties. Furthermore, Tamhane et al. (1970) stressed that the stability of the aggregates (i.e. degree of resistance against disintegrating forces of water and physical action) is most important factor in the structural behavior of a soil. Cultivation is one of the major factors that break the defensive measure of the soil structural aggregates, so soil structural stability usually decreased with cultivation (Moreau, 1978; Six et al., 2000; Eynard et al., 2004). Similarly, Babalola \& Chielda (1972) and Kowalinski et al. (1982) reported that cultivated soils were less stable and have predominantly small aggregates compared with the virgin soils. A stable porous surface soil structure is important for maintaining favorable soil physical condition for plant growth (Chan et al., 1994). This stability, however, was found to be reduced when a permanent pasture was being ploughed (Low 1972; Russell, 1973).

The soil stability also influenced by the rate at which wetting takes place, the pressure of entrapped air and the extent of differential swelling (Grant \& Dexter, 1990). When stability is measured under relatively wet condition, it is noted that it is decreasing with water content (Kay \& Dexter, 1990; Perfect et al., 1990; Gollany et al., 1991). The ability of the dry aggre gates to disintegrate upon contact with water was noticed to be greatest in the conventionally tilled and least in the untilled soils (Mbagwu \& Bazzoffi, 1989). Pagliai (2005) observed that stable macro-aggregate in wet sieving of tilled soil is lower than that of no tilled soil due to aggre gate break down in tillage process.

Further more land use type or system has been found also to affect the structural stability of the soil aggregates. Mbagwu \& Auerswald (1999) observed that land use influenced structural stability more than intrinsic soil properties and that percolation stability of soil increased with increase in organic matter content. Therefore, with cultivation processes, poorly structured soils will be easily eroded. Perennial crops generally improve soil structure, while annual row cropping often results in structural degradation, mainly as a result of a loss of ground cover and organic matter losses from soil disturbance (Magdoff \& Van Es, 2000; Karunatilake \& Van Es, 2002), is of the view that increased soil disturbance from tillage can further accelerate soil degradation when perennial crops are converted to annual row crops. Soil structure and aggregation are strongly influenced by tillage related practices (Holeplass et al., 2004; Khurshid et al., 2006), cropping systems and climate (Guerif et al., 2001). Still with regard to land use, Han et al. (2007) reported higher content of water stable aggre gates in orchard than in annual upland crops. Therefore, a sound knowledge of the spatial variability of soil properties / stability as it relates to soil type and land use system will be a good management practices and land use planning for agricultural sustainability and environmental harmony. Thus this study was undertaken to investigate the aggregate stability of four soils; Entisol, Ultisol, and two Inceptisols under different land use system as evaluated by different indices.

\section{Materials and Methods}

\subsection{Collection and classification of soil samples}

Soil samples were collected from the depth of $0-25 \mathrm{~cm}$ from cultivated and adjacent fallow lands of four different locations in Nsukka area of southeastern Nigeria. Care has been taken to minimize disturbance during sampling and transportation. The study area has a rainforest savannah type of vegetation with a mean annual temperature of $24^{\circ} \mathrm{C}$.The area lies within latitude $06^{\circ} 61^{\prime} \mathrm{N}$ and longitude $07^{\circ} 25^{\prime} \mathrm{E}$ of Nigeria. The soil samples which were collected from the Eha-Amufu and Ikem locations were hydromorphic types. These soils were cracks when it dry while it becomes sticky when wet, this phenomena presenting the problems in the tillage operations. The soils samples for the study were classified according to Soil Taxonomy as an Ultisol, belonging to the sub-group, Typic Kandiustult (Nkpologu series), Entisol belonging to Lithic Ustorthent (Uvuru series), while the other two soils belong to Vertic Inceptisol (Soil Survey Staff, 1992).These soils have been under cultivation for over or about 8years while fallow soils varied from 3 to 4 years old. The paramount crop culture in the study area is mixed cropping whereby the farmers' plant deep rooted and shallow rooted crops together on the same piece of land. Some examples of these mixed crops were cassava, yam, maize, pumpkin, okra, etc.

\subsection{Laboratory characterization of soil samples}

Collected soil samples were air-dried at room temperature and sieved through a $5 \mathrm{~mm}$ sieve. Soil clumps were carefully crushed by hand along lines of natural cleavages to pass the sieve. Two hundred and fifty grams $(250 \mathrm{~g})$ of the sieved sample, at a time, were transferred to the upper most of a nest sieve of sizes 2, $1,0.5$ and $0.25 \mathrm{~mm}$. These samples were shaken mechanically for 10 minutes. Further sieving by hand was done where necessary. This procedure, similar to that described by Kemper \& Chepil (1965), resulted in the separation of the following aggregate fractions 5-2, 2-1, 1-0.5, $0.5-0.25$ and $<0.25 \mathrm{~mm}$. The separation continued until enough quantity of each fraction was collected for further analysis. 
Table 1 Location, soil classification and land use.

\begin{tabular}{|c|c|c|c|c|c|c|}
\hline Location & $\begin{array}{l}\text { Soil } \\
\text { Classification }\end{array}$ & $\begin{array}{l}\text { Treatment } \\
\text { symbol }\end{array}$ & Land use & Type of tillage & $\begin{array}{l}\text { Cropping } \\
\text { system }\end{array}$ & Crop grown \\
\hline $\begin{array}{l}\text { Nsukka } \\
\text { Hill site }\end{array}$ & $\begin{array}{l}\text { Lithic } \\
\text { Ustorthent } \\
\text { (Uvuru series) }\end{array}$ & $\begin{array}{l}\text { ENsk (F) } \\
\text { ENsk (E) }\end{array}$ & $\begin{array}{l}\text { Fallow } \\
\text { Cultivated }\end{array}$ & $\begin{array}{l}\text { Conventional } \\
\text { tillage }\end{array}$ & $\begin{array}{l}\text { Mixed } \\
\text { Cropping }\end{array}$ & $\begin{array}{l}\text { Cassava (Manihot esculenta) } \\
\text { Yam (Dioscorea rotundata) } \\
\text { Maize (Zea mays) } \\
\text { Okra (Abelmos chus } \\
\text { esculentus) }\end{array}$ \\
\hline $\begin{array}{l}\text { Nsukka } \\
\text { poultry } \\
\text { site }\end{array}$ & $\begin{array}{l}\text { Ultisol } \\
\text { (Nkpologu } \\
\text { series) }\end{array}$ & $\begin{array}{l}\text { UNsk (F) } \\
\text { UNsk (C) }\end{array}$ & $\begin{array}{l}\text { Fallow } \\
\text { Cultivated }\end{array}$ & $\begin{array}{l}\text { Conventional } \\
\text { tillage }\end{array}$ & $\begin{array}{l}\text { Mixed } \\
\text { Cropping }\end{array}$ & $\begin{array}{l}\text { Cassava (Manihot esculenta) } \\
\text { Yam (Dioscorea rotundata) } \\
\text { Maize (Zea mays) }\end{array}$ \\
\hline $\begin{array}{l}\text { Eha- } \\
\text { Amufu } \\
\text { site }\end{array}$ & Vertic Inceptisol & $\begin{array}{l}\text { IEh (F) } \\
\operatorname{IEL}(\mathrm{C})\end{array}$ & $\begin{array}{l}\text { Fallow } \\
\text { Cultivated }\end{array}$ & $\begin{array}{l}\text { Conventional } \\
\text { tillage }\end{array}$ & $\begin{array}{l}\text { Mixed } \\
\text { Cropping }\end{array}$ & $\begin{array}{l}\text { Cassava (Manihot esculenta) } \\
\text { Yam (Dioscorea rotundata) } \\
\text { Maize (Zea mays) } \\
\text { Pumpkin (Telfairia } \\
\text { occidentalis) }\end{array}$ \\
\hline Ikem site & Vertic Inceptisol & $\begin{array}{l}\text { Iik }(F) \\
\operatorname{Lik}(C)\end{array}$ & $\begin{array}{l}\text { Fallow } \\
\text { Cultivated }\end{array}$ & $\begin{array}{l}\text { Conventional } \\
\text { tillage }\end{array}$ & $\begin{array}{l}\text { Mixed } \\
\text { cropping }\end{array}$ & $\begin{array}{l}\text { Cassava (Manihot esculenta) } \\
\text { Yam (Dioscorea rotundata) } \\
\text { Maize (Zea mays) }\end{array}$ \\
\hline
\end{tabular}

\subsection{Determination of Aggregate Stability}

\subsubsection{Mean-Weight Diameter of Dry Aggregate (MWDD)}

Mean-weight diameter of dry aggregates was measured by the method describe by the Kemper \& Chepil (1965). This method involved horizontal vibrating $250 \mathrm{~g}$ of dry soil on a mechanical shaker for 10 minutes on top of a nest of sieves of diameters 2 , $1,0.5$ and $0.25 \mathrm{~mm}$ and determining the mass of aggregates on each sieve that resisted break down. The mean weight diameter of dry aggregate (MWDD) was computed thus

MWDD $=\quad \overline{\mathrm{Xi}}$ di ------------ (1)

Whereas:

MWDD $=$ Mean-Weight Diameter of Dry Aggregates $(\mathrm{mm})$ $\overline{\mathrm{X}}=$ Mean Diameter of each size fraction $(\mathrm{mm})$

$\mathrm{di}=$ proportion of total sample weight occurring in the corresponding size fraction.

\subsubsection{Mean-Weight Diameter of Wet Aggregates (MWDW)}

The method of Kemper (1965) was used to determine the mean-weight diameter of wet aggregates. In accordance with the procedure, $40 \mathrm{~g}$ of soil was pre-soaked for 5 minutes on the top most sieves of diameters $2,1,0.5$ and $0.25 \mathrm{~mm}$, then vertically oscillated for 20 times at the rate of 1 oscillation per second. The resistant aggregates were oven-dried and their masses recorded. The mean weight diameter of wet aggregates (MWDW) was computed thus,

MWDW $=\quad$ XiWi--

Whereas:

MWDW = Mean-Weight Diameter of Wet Aggregates $(\mathrm{mm})$ $\mathrm{Xi}=$ Mean Diameter of each size fraction $(\mathrm{mm})$
$\mathrm{Wi}=$ Proportion of total samples weight occurring in the corresponding size fraction.

The geometric mean-weight diameter of both dry and wet sieve samples was evaluated by calculation.

\subsection{Data Analysis}

Steel \& Torrie (1980) procedure of statistics analysis was use d to analyze the data obtained and LSD at 0.05 was used to compare treatment means.

\section{Results and Discussion}

\subsection{Aggregate Stability of the Soils}

MWDD of cultivated and fallow soils did not differ significantly with the exception of UNsk where MWDD in cultivated soil increased significantly over fallow soil by 12.2 percent (Table 2). Similar results were obtained for MWDW, GMDD and GMDW. The exceptions were IEh for MWDW and Iik for GMDD. For GMDW, fallow soil in IEh increased significantly over cultivated by 4.2 percent. For the rest of the soils, marginal differences was reported between fallows and cultivated but these were not significantly differing. The non significant variation between fallow and cultivated soil in the stability parameters could be attributed to the short fallow period. Aggregation processes are generally time dependent even under favorable conditions. Furthermore, good soil management under cultivated conditions could significantly reduce the de gree of aggregate break down. That is contrary to the observation of Moreau (1978), that aggregate stability is reduced by cultivation. The mixed crop culture observed in the studied soils might have influenced the nature of the result obtained. Furthermore, Guerif et al. (2001) noted that cropping system influence the soil aggregation but the effect of tillage practices are merely reported in the condition of using Hoe 
which will have less impact on soil aggregates compared to if machines were to be used on the soils. Contradictory opinion were given by Holeplass et al. (2004) and Khurshid et al. (2006) that soil aggregations are strongly influenced by tillage related practices. Nevertheless, the mean-weight diameter of dry aggre gate is not very sensitive in detecting differences among various land use type (Mbagwu \& Bazzoffi, 1989).

The mean-weight diameter of wet Aggregates (MWDW) of the cultivated soils were higher than those of the fallow soils with the exception of IEh where the cultivated value was low compared to the fallow soil, these values show contrary indication that cultivation reduced the aggregate stability of soils. The cultural practices such as manure application or plant remains in the cultivated fields may increased the aggregation stability of the soils probable through organic matter and clay accumulation. Kladivko et al. (1986) argued that stability of aggregates is mainly determined by the type of plant remains.

While Reichert \& Norton (1994) stressed that cultivation history of a soil influences its aggregation. The result have also be dependent on the texture of the soils, as it was observed that most of the cultivated soils had more clay content than the fallow soils (Nweke, 2015) and clay value is one of the useful index in soil aggregation. Similarly, Frankel et al. (1978) also observed that texture and organic matter accumulation influence soil aggregation. The IEh cultivated showed significant difference $(\mathrm{P}=0.05)$ among the values obtained from the other soil types and land use systems. The relative percentage increases due to cultivation were $6.3,3.2$ and 2.9 percent for ENsk, UNsk and Iik, respectively. The relative decrease for the IEh was 50 percent (Table 2). This particular value indicates that the aggregates disintegrated fast when they came in contact with water, necessitating the higher variability compared with dry sieving. For the IEh, the MWDW is very sensitive in detecting the disaggregation in stability between the fallow and cultivated treatments which probably may be due to organic matter losses from soil disturbance (Magdoff \& Van Es, 2000), an observation made also by Mbagwu \& Bazzoffi (1989) with temperate soils. Long period under cultivation for vulnerable soils leads to serious decline in the stability of soil aggregates which may affect crop production depending on rainfall distribution and intensity, leaves the landscape vulnerable to serious erosion (Quirk, 1979).

The geometric mean-diameter of dry sieved aggregates (GMDD) of the cultivated soils was higher relative to the fallow soils. The exception is the ENsk where the cultivated value was lower than the fallow soil. While the Iik cultivated soil showed significant differences $(\mathrm{P}=0.05)$ among all the soil types and land use system studied. The percentage increase in dry aggregates stability of these soils relative to fallow soils were 2.0, 3.7, 4.1 and 13.9 percent for the ENsk, UNsk, IEh and Iik, respectively (Table 2). The value of GMD obtained from ENsk, however indicates that cultivation reduced the aggregate stability of the soil. This probable may be associated with the mixed crop culture practiced in the studied soils.

The result of the GMD obtained for wet sieved UNsk and IEh showe d that cultivation reduced the aggregate stability of these soils (Table 2). A contrary result obtained from ENsk and Iik indicates an increase in the aggregate stability due to cultivation. The relative percentage decrease for the UNsk and IEh relative to the cultivated soil was 1.4 and 23.5 percent respectively. Though the effect of cultivation is little in UNsk compared to the IEh, the values indicate that the aggregates disintegrated faster when they come in contact with water, necessitating the higher variability compared with dry sieving. The hydration and dehydration processes observed in soils when it came in the contact with water might have necessitated the variation observed in the dry and wet sieving.

Table 2 Aggregate Stability of Fallow and Cultivated soils as evaluated by different indices

\begin{tabular}{|lcccc|}
\hline Soils & MWDD $(\mathbf{m m})$ & MWDW $(\mathbf{m m})$ & GMDD $(\mathbf{m m})$ & GMDW $(\mathbf{m m})$ \\
\hline ENsk $(\mathrm{F})$ & 1.73 & 0.60 & 0.98 & 0.89 \\
\hline ENsk (C) & 1.66 & 0.64 & 0.96 & 0.93 \\
\hline UNsk (F) & 1.08 & 0.30 & 0.81 & 0.71 \\
\hline UNsk (C) & 1.23 & 0.31 & 0.97 & 0.71 \\
\hline IEh (F) & 1.76 & 0.56 & 1.01 & 0.85 \\
\hline IEh C & 1.83 & 0.28 & 1.01 & 0.65 \\
\hline Iik F & 1.90 & 0.67 & 1.15 & 0.92 \\
\hline Iik C & 2.00 & 0.69 & 0.97 & 0.96 \\
\hline Mean & 1.65 & 0.51 & 0.05 & 0.83 \\
\hline LSD 0.05 & 0.5 & 0.08 & 0.06 \\
\hline
\end{tabular}

$\mathrm{F}=$ Fallow; $\mathrm{C}=$ Cultivated; ENsk $=$ Entisol at Nsukka; UNsk = Ultisol at Nsukka; IEh $=$ Inceptisol at Eha - Amufu; Iik $=$ Inceptisol at Ikem. LSD = Least Significant Difference. MWDD = Mean - weight diameter of dry aggregates, MWDW = Mean - weight diameter of wet aggregates. GMDD = Geometric mean- weight diameter of dry aggregates, GMDW = Geometric mean - weight diameter of wet aggre gates. 
This invariable will influence the formation and re-orientation of clay particles that will have different impact in aggregation and disaggregation of soil aggregates. Zonn (1986) observed that alternating processes of hydration-dehydration with swelling and compression peculiar with vertic soils result in reorientation of clay particles, also the variation may be due to aggre gates breakdo wn caused by entrapped air during wetting. Le Bissonnais (1996) observed that high disaggregation in aggregates on contact with water especially soils with vertic properties are due to breakdown caused by compression of entrapped air during fast wetting or breakdown by differential swelling during fast wetting. The relative percentage increases due to cultivation for the ENsk and Iik were 4.3 and 4.2 percent respectively relative to the fallow soils. These results supported the findings of Gloria \& Eleonora (2006), those who have observed that several mechanisms are involved in the destabilization of soil aggregates under wetting including slaking, swelling and dispersion of the clay and mechanical breakdown by abrasion, which may vary according to the pretreatment of the sample (Pojasok \& Kay, 1990; Dickson et al., 1991) and the operation functions (Dickson et al., 1991; Amezketa et al., 1996 ; Schjonning et al., 2002; Castro Filho et al., 2002; Rohoskova \& Valla, 2004; Eynard et al., 2004).

\section{Conclusion}

The result of the study showed marginal but non-significant variation in aggregate stability parameter studied under cultivated and fallow soils. The short fallow period of four years might not have been adequate for significant aggregate stabilization over the cultivated soils. Secondly, good soil management practices under cultivated condition could reduce the rate of aggregate break down. There has to be a land use strategy to maintain stable aggregation but at the same time allow an ordered agricultural production of crops. Knowledge of the soils structural behavior within different land use regimes must be such as to allow flexibility of management without undue risk.

\section{Conflict of interest}

Authors would hereby like to declare that there is no conflict of interests that could possibly arise.

\section{References}

Amezketa E, Singer MJ, Le Bissonnais Y (1996) Testing a New Procedure for Measuring Water-Stable Aggre gation. Soil Science Society of American Journal, 60:88-894. doi:10.2136/sssaj1996.03615995006000030030x

Babalola O, Chielda HR (1972) Effects of crops and management system on soil structure in a Western Nigeria soil. Nigerian Journal Science 6:29-36.

Castro Filho C, Lourenço A, Guimarães M deF, Fonseca ICB (2002) Aggregate stability under different soil management systems in a red latosol in the state of Parana, Brazil. Soil and

Tillage Research 65:45-51. doi:10.1016/S0167-
1987(01)00275-6.

Chan KY, Heenan DP, Ashley R (1994) Seasonal changes in surface aggregate stability under different tillage and crops. Soil and Tillage Research 28:301-314. doi:10.1016/01671987(94)90137-6.

Dickson EL, Rasiah V, Groenevelt PH (1991) Comparison of four prewetting techniques in wet aggregate stability determination. Canadian Journal of Soil Science 71:67-72.doi: 10.4141/cjss91-006.

Eynard A, Schumacher TE, Lindstrom MJ, Malo DD (2004) Aggregate sizes and stability in cultivated So uth Dakota Prairie Ustolls and Usterts. Soil Science Society American Journal 68:1360-1365.

Frankel H, Goertzen JO, Rhoades JD (1978) Effect of clay types and content exchangeable sodium percentage and electrolyte and concentration on clay dispersion and hydraulic conductivity. Soil Science Society of America Journal 42: 32 39. doi:10.2136/sssaj1978.03615995004200010008x.

Gloria F, Eleonora B (2006) Destabilization of aggregates in some Typic Fragiudalfs. Soil Science, 171:272-281. doi: 10.1097/01.ss.0000199703.76278.80.

Gollany HT, Schumacher TE, Evenson PD, Lindstrom MJ, Lemme GD (1991) Aggregate Stability of an Eroded and Desurfaced Typic Argiustoll. Soil Science Society of America Journal 55:811-816. doi:10.2136/sssaj1991.03615995005500030030x.

Grant CD, Dexter AR (1990) Air entrapment and differential swelling as factors in the mellowing of molded soil during rapid wetting. Australian Journal of Soil Research 28:361-369. doi:10.1071/SR9900361.

Guérif J, Richard G, Dürr C, Machet J.M, Recous S, RogerEstrade J (2001) A review of tillage effects on crop residue management, seedbed conditions and seedling establishment. Soil and Tillage Research 61:13-32. doi:10.1016/S01671987(01)00187-8.

Han KH, Cho HJ, Lee HS, Oh DS, Kin LY (2007) Stable macro-aggregates in wet sieving and soil properties. Korean Journal of Soil Science and Fertility 40:251-255.

Holeplass H, Singh BR, Lal R (2004) Carbon sequestration in soil aggregates under different crop rotations and nitrogen fertilization in an inceptisol in southeastern Norway. Nutrient Cycling in Agroecosystems 70:167-177. doi: 10.1023/B:FRE S.0000048483.94397.b6.

Karunatilake UP, van Es HM (2002) Rainfall and tillage effects on soil structure after alfalfa conversion to maize on a 
clay loam soil in New York. Soil and Tillage Research, 67:135-146. doi:10.1016/S0167-1987(02)00056-9.

Kay BD, Dexter AR (1990) Influence of aggregate diameter, surface area and antecedent moisture content on the dispersibility of clay. Canadian Journal of Soil Science, 70: 655-671.doi: 10.4141/cjss90-068.

Kay BD, Munkholm LJ (2004) Management induced soil structure degradation, organic matter depletion and tillage. In: Schjonning P, Elmholt S, Christensen BT (Eds.) Managing soil quality: Challenges in modern Agriculture, CABI publication, Wallingford UK Pp185-197.

Kemper WD (1965) Aggregate stability. In: Black CA (Ed) Methods of Soil Analysis. Part 1. Physical and Mineralogical Properties, Including Statistics of Measurement and Sampling, Agronomy Monograph 9.1. American Society of Agronomy, Soil Science Society of America Madison Pp 511-519.doi: doi:10.2134/agronmonogr9.1.c40.

Kemper WD, Chepil WS (1965) Size distribution of aggre gates. In: Black CA (Ed) Methods of Soil Analysis. Part 1. Physical and Mineralogical Properties, Including Statistics of Measurement and Sampling, Agronomy Monograph 9.1. American Society of Agronomy, Soil Science Society of America Madison Pp. 499-510.doi: doi:10.2134/agronmonogr9.1.c39.

Khurshid K, Iqbal M, Arif MS, Nawaz A (2006) Effect of Tillage and Mulch on Soil Physical Properties and Growth of Maize. International Journal of Agriculture and Biology 8: 593-596.

Kladivko EJ, Mackay AD, Bradford JM (1986) Earthworms as a factor in the reduction of soil crusting. Soil Science Society of America Journal 50:191-196. doi:10.2136/sssaj1986.03615995005000010036x.

Kowalinski S, Drozd T, Lieznar M (1982) Characterization of the physico-chemical properties of structural aggregates of various sizes. Polish Journal of Soil Science 15:119-127.

Le Bissonnais Y (1996) Aggregate stability and assessment of soil crustability and erodibility: I. Theory and methodology. European Journal of Soil Science 47: 425-437. doi: 10.1111/j.1365-2389.1996.tb01843.x.

Low A J (1972) The effect of cultivation on the structure and other physical characteristics of grassland and arable soils (1945-1970). Soil Science 23:363-380.

Magdoff FR, Van Es HM (2000) Building soils for better Crops. $2^{\text {nd }}$ edn. Hand book series Book 4. Sustainable Agriculture Beltriville, MD, Pp 240.

Mbagwu JSC, Auerswald K (1999) Relationship of percolation stability of soil aggregates to land use, selected properties, structural indices and simulated rainfall erosion. Soil and Tillage Research 50:197-206. doi:10.1016/S01671987(99)00006-9.

Mbagwu JSC, Bazzoffi P (1989) Properties of soil aggregates as influenced by tillage practices. Soil Use and Management 5:180-188

Moreau R (1978) Effect of mechanical loosing and water infiltration on the structural stability of a ferralitic soil in central Ivory Coast. Orstom for pedologie, 413-424. doi: 10.1111/j.1475-2743.1989.tb00781.x.

Neves CSVJ, Feller C, Guimaraes MF, Medina CC, Tavares Filho J, Fortier M (2003) Soil bulk density and porosity of homogeneous morphological units identified by the Cropping Profile Method in clayey Oxisols in Brazil. Soil and Tillage Research 71:109-119. doi:10.1016/S0167-1987(03)000230 .

Nweke IA (2015) Physical and chemical properties of four contrasting soils under different land use systems. Advances in Research 3: 236-243. doi : 10.9734/AIR/2015/11790

Pagliai U (2005) Soil Crusting, paper presented at 2005 college of soil physics ICIP Trieste Italy September, 2005.

Perfect E, Kay BD, van Loon WKP, Sheard RW, Pojasok T (1990) Rates of change in soil structural stability under forages and corn. Soil Science Society of America Journal 54:179-186. doi:10.2136/sssaj1990.03615995005400010028x.

Pojasok T, Kay BD (1990) Assessment of a combination of wet sieving and turbidimetry to characterize the structural stability of moist Soils. Canadian Journal of Soil Science, 70:33-42.doi: 10.4141/cjss90-004.

Quirk JP (1979) The nature of aggregate stability and implications for management. In: Lal R, Greenland DJ (Eds.), Soil Physical Properties and Crop Production in the Tropics. John Wiley \& Sons, New York, NY, Pp. 57-74.

Reichert JM, Norton LD (1994) Aggregate stability and rain impacted sheet erosion of air dried and pre-wetted clay surface soils un der intense rain. Soil Science 158: 159-169.

Rohoskova M, Valla M (2004) Comparison of two methods for aggregate stability measurement. A review. Plant, Soil and Environment 50:379-382.

Russell EW (1973) Soil condition and plant growth. $10^{\text {th }}$ edn, Longman group, London, Pp. 849.

Schjonning P, Elmholt S, Munkholm LJ, Debosz K (2002) Soil quality aspects of humid sandy loam as influenced by organic and conventional long-term management. Agriculture, Ecosystem and Environment 88:195-214. doi:10.1016/S01678809(01)00161-X. 
Six J, Paustian K, Elliott ET, Combrink C (2000) Soil structure and organic matter. I. Distribution of aggregates size classes and aggregate associated carbon. Soil Science Society of America Journal, 64:681-689. doi:10.2136/sssaj2000.642681x.

Soil Survey Staff (1992) Soil Taxonomy: A basic system of soil classification for making and interpreting soil surveys. USDA-SCs A gric. Han d book 436. U.S. Govt. Printing Office, Washington D.C.
Steel RG, Torrie JH (1980) Procedure of statistics a biometric approach $2^{\text {nd }}$ edition, McGraw Hill Company, Inc. NY. Pp633.

Tamhane RV, Motiramani DP, Bali YP (1970) Soils; their chemistry and fertility in Tropical Asia. Prentice Hall of India Private Ltd. Pp 475.

Zonn SV (1986) Tropical and sub-tropical soil science, English version. Mir publishers Moscow Pp.270-271. 